\title{
Immune Responses of Diabetic Animals
}

\section{Comparison of Genetically Obese and Streptozotocin-Diabetic Mice}

\author{
W. K. Nichols, J. B. Spellmann, and R. A. Daynes \\ Department of Biopharmaceutical Sciences, College of Pharmacy, and Departments of Pharmacology and Pathology, College of Medicine, \\ University of Utah, Salt Lake City, Utah, USA
}

\begin{abstract}
Summary. The blastogenic responses of lymphocytes from chemically-induced (streptozotocin) and genetically-diabetic C57Bl/6J (ob/ob) obese mice were assessed using mixed-lymphocyte cultures (MLC) and mitogens selective for thymus-derived ( $\mathrm{T}$ cell) and bone marrow-derived (B cell) lymphocytes. Splenic lymphocytes from obese and normal C57Bl/6 mice exhibited similar responses to the nonspecific $T$ and $\mathrm{B}$ cell mitogens, Concanavalin $\mathrm{A}$ (Con $\mathrm{A}$ ) and $\mathrm{E}$. coli lipopolysaccharide (LPS), respectively. A small $(25 \%)$ depression of the blastogenic response in MLC was observed for lymphocytes from obese mice. The generation of cytotoxic $T$ cells in vitro in response to trinitrobenzene sulphonic acid (TNP)modified syngeneic spleen cells was the same for normal and obese mice. In contrast, splenic lymphocytes from 7-14 day streptozotocin-diabetic mice had lower $(56-60 \%)$ proliferative responses in MLC. The generation of cytotoxic effector cells in vitro was lower for spleen cells from 22-day streptozotocin mice, although blastogenic responses in MLC were not depressed. The insulin-deficient streptozotocin mice appear to have a depression of some thymusderived cell functions that may be associated with streptozotocin rather than the diabetic state. Direct immunosuppressive effects of streptozotocin are indicated by the marked decrease in the number of lymphocytes in the thymus, lymph nodes, and spleen.
\end{abstract}

Key words: Diabetes, lymphocytes, (ob/ob), obese mice, streptozotocin, spleen cells, lymphocyte-mediated cytotoxicity, mixed lymphocyte reactions, lymphocyte transformation, Con A.

Patients with diabetes mellitus have been considered to be at greater risk for some infectious diseases such as tuberculosis because many of these patients died prior to the availability of insulin therapy [1]. Some illnesses in diabetics tend to be more protracted and severe [2]. Cellular immunological responses tested in vitro using phytohemagglutinin (PHA) have been suppressed in diabetic patients under poor metabolic control $[3,4]$ but not in well-controlled diabetics $[4$, 5]. A suppression of PHA-induced blastogenesis for lymphocytes from alloxan-diabetic rats has been reported by this laboratory $[6,7]$. Recently, Brown et al. [8] reported that spleen cells from streptozotocindiabetic mice had decreased blastogenic responses to $\mathrm{T}$ cell mitogens and decreased cytotoxic responses against allogeneic tumour cells when sensitized either in vivo or in vitro. The same investigators also observed depressed $\mathrm{T}$ cell-mediated cytotoxicity responses for spleen cells from genetically obese mice when sensitized in vivo, but not in vitro. Mahmoud et al. [9] found that insulin reversed defects in some cell-mediated immune responses observed in vivo using chemically-induced (alloxan and streptozotocin) diabetic mice. However, the failure of insulin to overcome the inhibitory effect of alloxan-diabetic rat plasma upon normal $\mathrm{T}$ cell blastogenesis in vitro suggests that other hormone or metabolic changes produced in vivo by a deficiency of insulin may be important [7].

Consequently, there may be a depression in the function of some $T$ cell population(s) in vivo in the diabetic, but this defect may not be observed in vitro. This report compares some normal and diabetic thymus-derived lymphocyte functions in vitro, using genetically obese and streptozotocin diabetic mice.

\section{Materials and Methods}

\section{Mice}

Genetically diabetic C57B1/6J ob/ob and normal $\mathrm{C} 57 \mathrm{~B} 1 / 6 \mathrm{~J}^{+} /+$female mice were purchased from Jackson Laboratories, Bar Harbor, Maine at an age 
of 8-10 weeks. Mice were used at 3-5 months of age. For experiments involving mice suffering from chemically-induced diabetes, $\mathrm{C} 57 \mathrm{Bl} / 6+/+$ male mice were purchased from Jackson Laboratories at 6-8 weeks of age. At 7-9 weeks, the mice were injected intravenously with streptozotocin (Sigma Chemical Company, St. Louis, Missouri) in saline $(8.5 \mathrm{~g} / \mathrm{l}), \mathrm{pH}$ 4.4 , at a dose of $125 \mathrm{mg} / \mathrm{kg}$ body weight. These mice were used 1,2 , or 3 weeks following injection, and age- and sex-matched C57Bl/6 animals which received no injection were used as controls. Nonfasting blood glucose levels of normal and streptozotocin-treated animals were measured immediately prior to use. Only streptozotocin-treated mice whose blood glucose levels were at least $400 \mathrm{mg} / 100 \mathrm{ml}$ were used in these studies. Male $\mathrm{C} 3 \mathrm{Hf} / \mathrm{HeN}$ mice were obtained from Charles River (Wilmington, Massachusetts). While maintained in our laboratory, the mice received $\mathrm{S} / \mathrm{L}$ Custom Lab Diet-G4.5 (Simonsen Laboratories, Inc., Gilroy, California) and tap water ad libitum.

\section{Mitogen Assays}

Cell cultures for mitogen assays were prepared essentially according to the methods of Janossy and Greaves [10]. Spleen cell suspensions were prepared in RPMI 1640 (K. C. Biological, Inc., Lenexa, Kansas) supplemented with $5 \% \mathrm{v} / \mathrm{v}$ fetal calf serum (K.C. Biological, Inc.); L-glutamine, $2 \mathrm{mmol} / \mathrm{l}$; penicillin, $50 \mathrm{U} / \mathrm{ml}$; streptomycin, $50 \mu \mathrm{g} / \mathrm{ml}(\mathrm{Mi}-$ crobiological Associates, Los Angeles, California); and 2-mercaptoethanol, $5 \times 10^{-5} \mathrm{~mol} / 1$ (Sigma Chemical Co.). This medium will be referred to as RPMI complete medium.

The mitogens, Concanavalin A (Sigma Chemical Company) and E. coli lipopolysaccharide (prepared and kindly donated by Dr. Charles DeWitt, University of Utah, Salt Lake City, Utah) were dissolved in RPMI complete medium, filter sterilized, and added to the cell cultures at concentrations indicated in the Results section.

All cultures were prepared in triplicate. Following $48 \mathrm{~h}$ incubation, the cultures were pulsed with 0.5 $\mu \mathrm{Ci}{ }^{3} \mathrm{H}$-thymidine $(1.9 \mathrm{Ci} / \mathrm{mmol}$ Schwarz-Mann, Orangeburg, New York), delivered in $5 \mu \mathrm{l} \mathrm{PBS}$, and incubated for an additional 24 hours. Cultures were harvested and counted in a Packard 3385 liquid scintillation system. The values for the triplicate samples were consistently within $15 \%$ of the given mean.

\section{One-Way Mixed-Lymphocyte Cultures}

Responder cells were obtained from spleens of $\mathrm{C} 57 \mathrm{Bl} / 6$ and $\mathrm{C} 57 \mathrm{Bl} / 6$ (ob/ob) or streptozotocin- treated $\mathrm{C} 57 \mathrm{Bl} / 6$ mice. Single spleen cell suspensions were prepared as described above in RPMI complete medium with $10 \%$ fetal calf serum (FCS). The cell density was adjusted to $8 \times 10^{6}$ cells per $\mathrm{ml}$. Mitomycin-C-treated $\left(30 \mu \mathrm{g} / \mathrm{ml}, 40\right.$ minutes, $\left.37^{\circ} \mathrm{C}\right)$ $\mathrm{C} 3 \mathrm{Hf} / \mathrm{HeN}$ spleen cells were used as stimulator cells. These cells were adjusted to the following densities in RPMI complete medium: $8 \times 10^{6} / \mathrm{ml}, 6.4 \times 10^{6} / \mathrm{ml}$, $4.8 \times 10^{6} / \mathrm{ml}, 3.2 \times 10^{6} / \mathrm{ml}$, and $1.6 \times 10^{6} / \mathrm{ml}$. Stimulator and responder cells were then added in $100 \mu \mathrm{l}$ volumes to each well of a Microtiter II culture plate, resulting in responder to stimulator (R:S) ratios of $5: 5,5: 4,5: 3,5: 2$, and $5: 1$. The cell cultures were incubated for 2,3 , or 4 days at $37^{\circ} \mathrm{C}$, pulsed with $0.5 \mu \mathrm{Ci}{ }^{3} \mathrm{H}$-thymidine, and incubated an additional 24 hours. The cells were harvested and isotope uptake measured as described for the mitogen assays. All cultures were done in quadruplicate, and the values for the four wells were $\pm 15 \%$ of the mean given in the Results section.

\section{In Vitro Sensitization and Cytotoxicity Assay}

For in vitro sensitization, single cell suspensions of spleen cells from normal $\mathrm{C} 57 \mathrm{Bl} / 6$ and $\mathrm{C} 57 \mathrm{Bl} / 6 \mathrm{ob} /$ $\mathrm{ob}$ or streptozotocin-injected $\mathrm{C} 57 \mathrm{Bl} / 6$ mice were prepared in RPMI complete medium with $10 \%$ FCS for use as responder cells. For use as stimulator cells, spleen cell suspensions from $\mathrm{C} 57 \mathrm{Bl} / 6$ mice were mitomycin-C treated as above and modified with trinitrobenzene sulphonic acid (TNP), according to the method of Shearer [11]. Cultures were then established in duplicate $50 \mathrm{ml}$ plastic tissue culture flasks with a final volume of $20 \mathrm{ml}$ RPMI complete medium with $10 \%$ FCS. Responder cells $\left(40 \times 10^{6}\right)$ were added to each flask, and $8 \times 10^{6}$ or $4 \times 10^{6}$ TNP-modified C57Bl/6 stimulator cells were also added so that $R: S$ ratios of $5: 1$ and $10: 1$ were obtained. Identical control flasks were prepared omitting the stimulator cells. After 5 days incubation, the cultures were harvested, centrifuged, and the cells were resuspended in $0.8 \mathrm{ml}$ RPMI complete medium with $10 \% \mathrm{v} / \mathrm{v}$ FCS. The number of viable cells was determined using trypan blue exclusion.

For assay of cytotoxicity, a modification of the original microassay by Takasugi and Klein [12] was used. Effector cells to be assayed were adjusted to 5 $\times 10^{7}$ cells per $\mathrm{ml}$ in RPMI complete medium with $10 \% \mathrm{v} / \mathrm{v}$ FCS. Two-fold serial dilutions of the effector cell suspension were then made. EL4 lymphoma cells ( $\mathrm{C} 57 \mathrm{Bl} / 6)$, maintained in vivo, were harvested for use as target cells. Labelling of the cells was accomplished by incubating the cell suspension at a density of $2 \times 10^{6}$ cells per ml with sodium ${ }^{51} \mathrm{Cr}$ chromate (specific activity $200-500 \mathrm{Ci} / \mathrm{g}$, New Eng- 
land Nuclear, Boston, Massachusetts. After 45 minutes of incubation, the cells were washed once, TNP-modified as above, washed three times, and finally adjusted to $5 \times 10^{5}$ cells per ml. One-hundred $\mu \mathrm{l}$ of the effector cell suspension and $100 \mu \mathrm{l}$ of the target cell suspension were then transferred in quadruplicate to the wells of a V-bottom microtiter tray (Cooke Laboratory Products, Alexandria, Virginia). Spontaneous release of ${ }^{51} \mathrm{Cr}$ from the target cells was determined by adding $100 \mu \mathrm{l}$ of labelled cells to four additional wells containing $100 \mu \mathrm{l}$ RPMI complete medium. For determination of maximum releasable ${ }^{51} \mathrm{Cr}, 100 \mu \mathrm{l}$ of labelled targets were added to $1.9 \mathrm{ml}$ distilled water. Following $4 \mathrm{~h}$ incubation, the microtiter plate was centrifuged, $100 \mu \mathrm{l}$ of supernatant was withdrawn from each well and placed in Beckman Biogamma vials for counting. One ml of supernatant was also removed from the distilled water tubes for counting. Percent specific ${ }^{51} \mathrm{Cr}$ release was calculated as

$$
\frac{(\text { Experimental })-(\text { Control })}{\left(\text { Distilled } \mathrm{H}_{2} \mathrm{O}\right)-(\text { Control })} \times 100 \text {. }
$$

The values for the quadruplicate samples were consistently within $10 \%$ of the mean stated in the Results section.

Statistical analysis of the data was performed using Student's t-test for unpaired groups.

\section{Results}

\section{Blastogenic Responses of Normal and Obese Mice}

The responses of spleen cells from normal $\mathrm{C} 57 \mathrm{Bl} / 6$ and obese (ob/ob) mice to a spectrum of Con A doses are shown for a representative experiment in Figure 1. Whole spleen cells from normal and obese mice are shown to be very similar over a wide range $(1-10 \mu \mathrm{g} / \mathrm{ml})$ of Con A doses. The blastogenic responses to LPS were the same for normal and obese spleen cells in 3-day cultures using doses of 1 , 10 , and $100 \mu \mathrm{g} / \mathrm{ml}$ (data not shown). When nonadherent spleen cells obtained from nylon wool columns were tested with the same doses of Con A as used for whole spleen cells, no differences were observed for normal and obese mouse lymphocytes (data not shown).

The blastogenic responses of splenic lymphocytes from obese and normal $\mathrm{C} 57 \mathrm{Bl} / 6$ mice were tested in one-way MLC against mitomycin-C treated C3Hf/ HeN spleen cells using various responder to stimulator cell $(\mathrm{R}: \mathrm{S})$ ratios. Table 1 presents the optimal responses of a representative experiment.
Table 1. Mixed-lymphocyte responses of spleen cells from normal and obese mice

\begin{tabular}{|c|c|c|c|c|c|c|}
\hline \multirow[t]{3}{*}{$\mathrm{R}: \mathrm{S}$} & \multicolumn{6}{|c|}{ Thymidine incorporation } \\
\hline & \multicolumn{3}{|c|}{ Normal } & \multicolumn{3}{|l|}{ Obese } \\
\hline & Day 3 & Day 4 & Day 5 & Day 3 & Day 4 & Day 5 \\
\hline $5: 5$ & 8,919 & 19,966 & 17,657 & 10,411 & 19,467 & $8,994^{\mathrm{a}}$ \\
\hline $5: 4$ & 8,779 & 25,185 & 18,722 & 10,470 & 19,566 & $12,471^{\mathrm{a}}$ \\
\hline 5:0 & 1,667 & 3,781 & 4,192 & 1,779 & 3,816 & 6,473 \\
\hline $0: 5$ & 153 & 123 & 103 & & & \\
\hline
\end{tabular}

Spleen cells are pooled from two normal or two obese mice Values are expressed as the mean cpm of quadruplicate cultures for ${ }^{3} \mathrm{H}$-thymidine incorporated the last $24 \mathrm{~h}$ of culture. The duration of one-way MLC is shown at the top of each column for the various responder-to-stimulator cell ratios $(R: S)$

a $\mathrm{p}<0.05$ compared with the corresponding normal control

The small $(20-30 \%)$ decreases in maximal thymidine incorporation by obese mice are not statistically significant in 4-day MLC at an $\mathrm{R}: \mathrm{S}$ ratio of $5: 4$. The obese spleen cell proliferative responses were depressed at 4 days, but no clear differences between obese and normal cells are apparent after only 3 days of culture. Obese mouse cells in two other experiments showed the same relatively small $(30 \%)$ decreases in MLC responses after 4 days of culture. These results suggest that differences in MLC observed for spleen cells from genetically obese and normal mice appear to be quite minimal. Accordingly, spleen cells from these animals were also compared in vitro using a $\mathrm{T}$ cell-mediated cytotoxicity assay.

\section{Comparison of In Vitro Cytotoxic Responses of Normal and Obese Spleen Cells}

TNP-modified syngeneic lymphocytes were incubated for 5 days with either normal or obese spleen cells to generate cytotoxic effector cells in vitro. Shearer [11] has demonstrated in a system using TNP-modified stimulator and target cells that killing is directed at modified syngeneic histocompatibility antigens rather than at the TNP moiety. There was no difference in the killing produced by normal and obese mouse lymphocytes over a broad range of effector to target cell (E:T) ratios (Fig. 2). The linear relationship between killing and increasing $E: T$ ratios indicated that the number of target cells is not limiting in these experiments. Therefore, the production of effector $T$ cells in vitro against a modified syngeneic target cell is not altered for lymphocytes from genetically obese diabetic mice. Subsequent studies of $T$ cell function were done using spleen cells from streptozotocin-treated mice. 


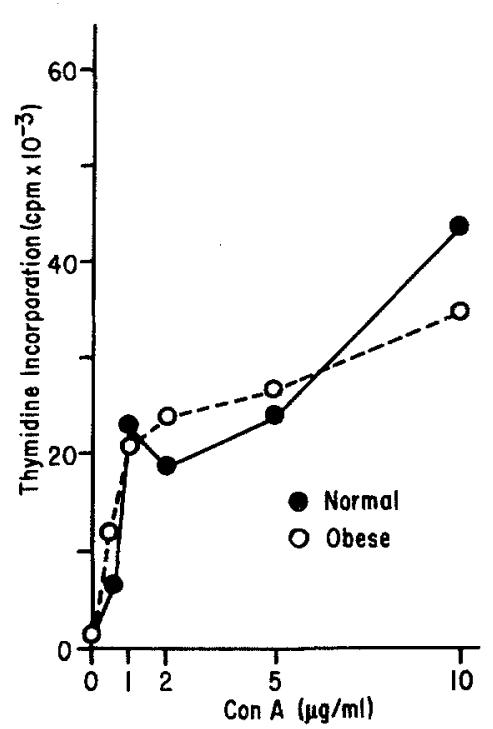

Fig. 1. Mitogen responses of spleen cells from normal (O) and obese $(O)$ mice. Spleen cells are pooled from three normal or three obese mice. Values represent the mean cpm of triplicate cultures for ${ }^{3} \mathrm{H}$-thymidine incorporated during the last $24 \mathrm{~h}$ of a three-day culture
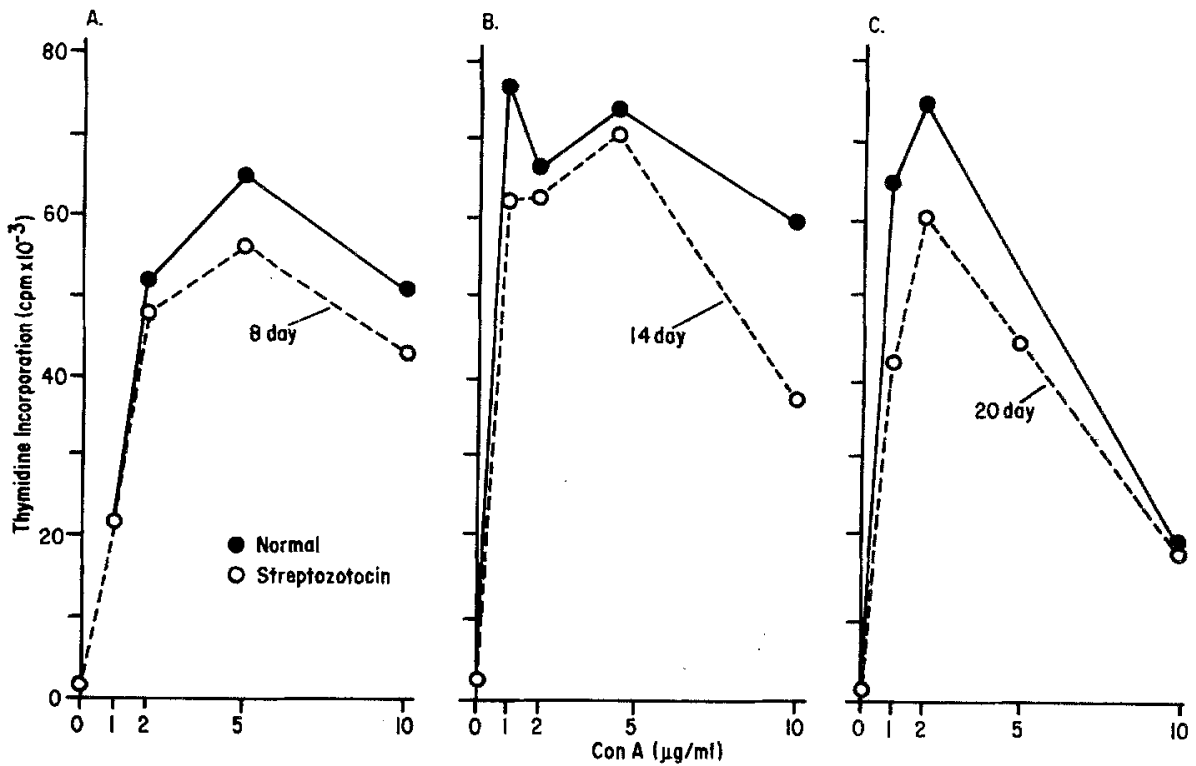

Fig. 3. Mitogen responses of spleen cells from normal (e) and streptozotocin (O) mice. Spleen cells are pooled from two or three mice and values are expressed as described in Figure 1. Figures $3 \mathrm{~A}, 3 \mathrm{~B}$, and $3 \mathrm{C}$ represent experiments comparing spleen cells of normal and diabetic mice at 8,14 , and 20 days after streptozotocin treatment. Only the splenic cells pooled from 20-day streptozotocin mice have maximal responses significantly less than normal $(\mathrm{p}<0.05)$

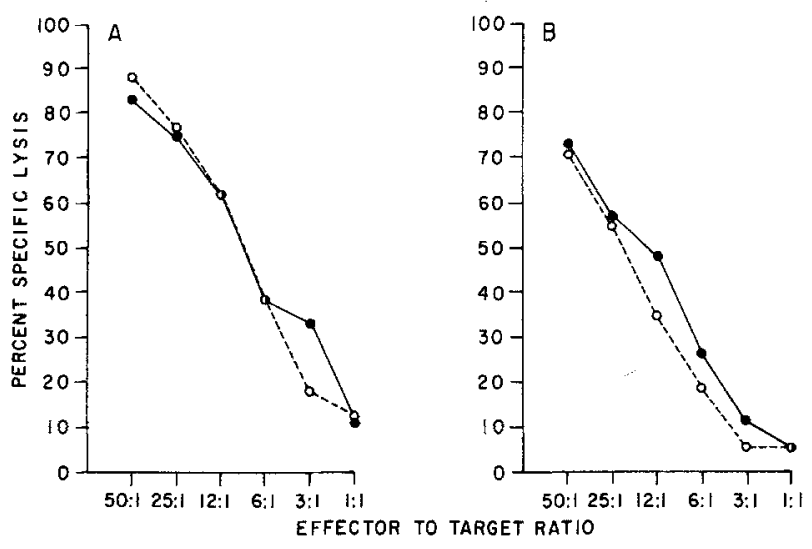

Fig. 2. Cytotoxicity of spleen cells from normal $(\bullet)$ and obese $(O)$ mice against TNP-modified EL-4 leukaemic cells. Spleen cells are pooled from four normal and four obese mice. Values represent the mean percent specific lysis of ${ }^{51} \mathrm{Cr}$ labelled TNP-modified target cells in quadruplicate cultures at the effector to target cell ratios $(E: T)$ shown for spleen cells sensitized in vitro using TNPmodified syngeneic spleen cells. Figures $2 \mathrm{~A}$ and $2 \mathrm{~B}$ represent the cytotoxicity responses of spleen cells sensitized at responder-tostimulator ratios $(R: S)$ of $5: 1$ and $10: 1$, respectively

\section{Blastogenic Responses of Lymphocytes from Normal and Streptozotocin-Diabetic Mice}

The blastogenic responses of spleen cells from normal and streptozotocin mice were compared using Con $\mathrm{A}$ at various doses. Mice that had been injected

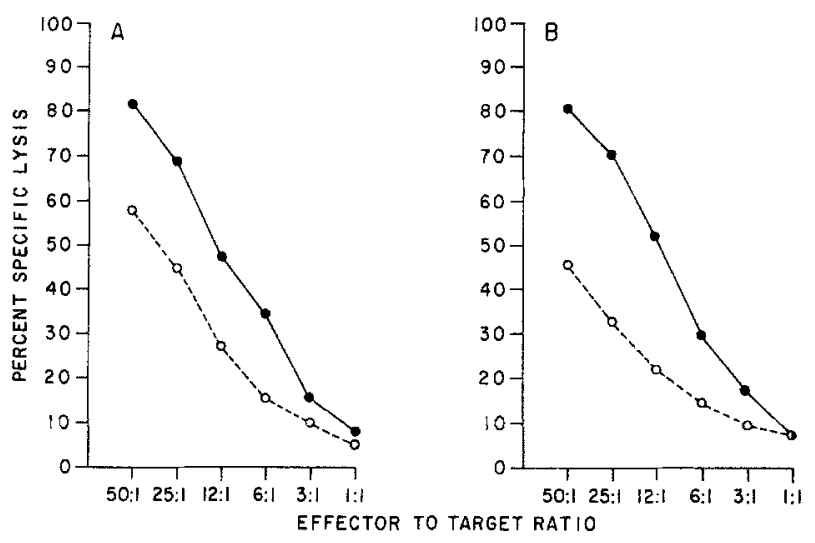

Fig. 4. Cytotoxicity of spleen cells from normal $(\bullet)$ and streptozotocin (O) mice against TNP-modified EL-4 lymphoma cells. Spleen cells are pooled from four normal and four 22-day streptozotocin mice and values are expressed as described in Figure 2. Figures $4 \mathrm{~A}$ and $4 \mathrm{~B}$ represent spleen cells sensitized at $\mathrm{R}: \mathrm{S}$ of $5: 1$ and $10: 1$, respectively. Spleen cells from streptozotocin mice are significantly less than normal $(p<0.001)$ for all $E$ : T ratios except $3: 1$ and $1: 1$

with streptozotocin 8-22 days earlier had plasma glucose levels that averaged $546 \pm 27(\mathrm{n}=19)$, compared to $145 \pm 4 \mathrm{mg} / 100 \mathrm{ml}(\mathrm{n}=19)$ for normal mice. The responses of splenic lymphocytes from the 8- and 14-day streptozotocin-diabetic mice were not significantly lower than the responses of normal mice 
Table 2. Mixed-lymphocyte responses of spleen cells from normal and streptozotocin-diabetic mice

\begin{tabular}{|c|c|c|c|c|c|c|c|}
\hline \multirow{2}{*}{$\begin{array}{l}\text { Days } \\
\text { post } \\
\text { strep. }\end{array}$} & \multirow[t]{2}{*}{$\mathbf{R}: \mathbf{S}$} & \multicolumn{3}{|c|}{$\begin{array}{l}\text { Thymidine incorporation } \\
\text { Normal }\end{array}$} & \multicolumn{3}{|c|}{ Streptozotocin } \\
\hline & & Day 3 & Day 4 & Day 5 & Day 3 & Day 4 & Day 5 \\
\hline 7 & $\begin{array}{l}5: 5 \\
5: 4 \\
5: 0\end{array}$ & $\begin{array}{r}10,060 \\
10,275 \\
1,268\end{array}$ & $\begin{array}{r}17,500 \\
17,196 \\
2,730\end{array}$ & 969 & $\begin{array}{l}4,406^{\mathrm{a}} \\
3,861^{\mathrm{a}} \\
1,402\end{array}$ & $\begin{array}{l}7,348^{\mathrm{a}} \\
7,088^{\mathrm{a}} \\
1,342\end{array}$ & $\begin{array}{l}9,498 \\
7,002\end{array}$ \\
\hline 13 & $\begin{array}{l}5: 5 \\
5: 4 \\
5: 0 \\
0: 5\end{array}$ & $\begin{array}{r}3,695 \\
4,264 \\
2,051 \\
201\end{array}$ & $\begin{array}{r}7,615 \\
10,179 \\
3,667 \\
127\end{array}$ & $\begin{array}{r}9,160 \\
9,260 \\
3,925 \\
149\end{array}$ & $\begin{array}{l}3,065 \\
2,622^{\mathrm{a}} \\
1,621\end{array}$ & $\begin{array}{l}4,876^{\mathrm{b}} \\
4,575^{\mathrm{a}} \\
2,385\end{array}$ & $\begin{array}{l}4,577^{\mathrm{a}} \\
5,491^{\mathrm{a}} \\
3,765\end{array}$ \\
\hline 20 & $\begin{array}{l}5: 5 \\
5: 4 \\
5: 0 \\
0: 5\end{array}$ & $\begin{array}{r}17,084 \\
17,922 \\
12,711 \\
49\end{array}$ & $\begin{array}{r}24,992 \\
28,550 \\
18,890 \\
36\end{array}$ & $\begin{array}{r}25,200 \\
27,826 \\
9,423 \\
28\end{array}$ & $\begin{array}{c}14,334^{\mathrm{b}} \\
13,105^{\mathrm{a}} \\
8,563\end{array}$ & $\begin{array}{l}22,015^{b} \\
20,238^{a} \\
19,033\end{array}$ & $\begin{array}{l}34,546^{a} \\
25,280 \\
12,608\end{array}$ \\
\hline
\end{tabular}

Spleen cells are pooled from two or three mice and the results are expressed as described in Table 1

a $\mathrm{p}<0.001$ compared with the corresponding normal control

b $\mathrm{p}<0.05$ compared with the corresponding normal control

to the mitogen (Fig. 3A and 3B). The peak responses of pooled 22-day streptozotocin splenic cells were about $20 \%$ less than normal spleen cell responses (Fig. $3 \mathrm{C}$ ). Lymph node cells from 22-day streptozotocin animals also had slightly lower $(20 \%)$ responses to optimal doses of Con A (not shown).

Proliferative responses by spleen cells from normal and streptozotocin-treated mice against mitomycin-C-treated $\mathrm{C} 3 \mathrm{Hf} / \mathrm{HeN}$ spleen cells are shown in Table 2 . The responses by normal and diabetic cells are presented for days 3,4 , and 5 at optimal responder to stimulator cell $(\mathrm{R}: \mathrm{S})$ ratios. The responses of lymphocytes from 7-day and 13-day streptozotocin-diabetic mice were $50-60 \%$ lower than the maximal blastogenic responses of normal lymphocytes observed after 3 or 4 days of culture. The 20-day streptozotocin spleen cells, however, had much smaller depressions of only $10-30 \%$ after 3 or 4 days of culture. A lower thymidine incorporation was apparent after 3-5 days of culture for the 7-13 day streptozotocin cells at most of the $R: S$ ratios tested, while a recovery is suggested for the 20-day streptozotocin cells. The observation that in vitro blastogenic responses of 20-day streptozotocindiabetic cells were not always less than normal spleen cells indicated that another in vitro assessment of $\mathrm{T}$ cell function should be examined. Consequently, spleen cells from streptozotocin-diabetic animals were tested for their ability to kill TNP-modified target cells in vitro.

\section{Comparison of In Vitro Cytotoxicity for Normal and Streptozotocin-Diabetic Mice}

The spleen cells from 22-day streptozotocin mice were compared with normal mouse splenic lympho- cytes for generation of cytotoxic $T$ cells in vitro (Fig.4). The cells from streptozotocin-diabetic animals appeared to effect significantly less killing of TNP-modified EL-4 target cells than did the lymphocytes from normal mice. When cultured at $R: S$ ratios of either $5: 1$ or $10: 1$, the 22-day streptozotocindiabetic spleen cells killed only $58 \%$ and $47 \%$ of the target cells compared to $82 \%$ by normal cells at the highest effector to target cell ratio tested. Other experiments have shown maximal killing of only $30 \%$ for streptozotocin-diabetic cells compared to $71 \%$ and $50 \%$ killing by normal cells cultured at $\mathrm{R}: \mathrm{S}$ ratios of $5: 1$ and $10: 1$, respectively. The killing by streptozotocin-diabetic cells was also significantly less than that observed for normal lymphocytes over a wide range of $\mathrm{E}: \mathrm{T}$ ratios. The potential direct effects of streptozotocin upon cells involved in the responses studied were assessed by counting the total number of cells in some lymphoid tissues.

\section{Changes in Lymphoid Tissue of Streptozotocin- Treated Mice}

The total amount of thymus tissue found in mice 7 , 14 , and 22 days after a single IV dose of streptozotocin is markedly reduced. The number of cells obtained from 7- to 14-day streptozotocin mice ranged from 2-4 $\times 10^{6}$ cells, while thymus tissue from normal mice yielded about $1 \times 10^{8}$ cells. Most animals had an almost total loss of thymus tissue by 7 days after streptozotocin treatment. The size of cervi$\mathrm{cal}$, brachial, and inguinal lymph nodes also was consistently less in 7- to 14-day streptozotocin animals. The numbers of spleen cells obtained from streptozotocin mice were not as reduced as those of thy- 
mus and lymph nodes and tended to show partial recovery after 13 days. The 7-, 13-, and 22-day streptozotocin mice had $20 \%, 33 \%$, and $34 \%$ of the number of spleen cells isolated from normal mice. These apparent drug-induced changes in spleen cell numbers did not parallel the changes in blastogenic responses observed in MLC (Table II). All animals were also shown to have a plasma glucose level of at least $400 \mathrm{mg} / 100 \mathrm{ml}$, so changes in the diabetic state between 13 and 20 days after streptozotocin did not appear to explain the changes in lymphocyte numbers or responses observed in these experiments.

\section{Discussion}

The present experiments compared the in vitro responses of lymphocytes from two types of diabetic animals: genetically obese mice, known to have markedly elevated plasma insulin levels [13], and streptozotocin-induced diabetic mice, characterized by a deficiency of insulin [14]. Splenic lymphocytes from obese mice had essentially normal blastogenic responses to $T$ cell and $B$ cell mitogens, although they expressed slightly lower responses in MLC to allogeneic lymphocytes. In addition, lymphocytemediated cytotoxicity was unaltered when spleen cells from genetically diabetic animals were sensitized in vitro using TNP-modified syngeneic lymphocytes. These results agreed with the observations of Brown et al. [8], who reported that lymphocytemediated cytotoxicity of obese mice was not altered when cells were sensitized in vitro, although cytotoxicity was depressed when the animals were sensitized in vivo. Consequently, the apparent depression of some cellular immune responses reported for obese mice in vivo $[8,9]$ may represent the influence of various physiological factors in the diabetic animal while the T cells involved may be normal when tested in vitro.

The in vitro experiments involving 7- and 13-day streptozotocin-diabetic mice, however, indicated that some $\mathrm{T}$ cell responses, such as proliferation induced by allogeneic cells are depressed, although mitogen responses to Con A were observed to be essentially normal. The depressed mixed-lymphocyte responses of streptozotocin-treated mice did tend to recover by day 20 , although the lymphocyte-mediated cytotoxicity of diabetic cells from animals 22 days after drug treatment were still notably depressed. The apparent recovery of mixed-lymphocyte responses observed between 13 and 20 days after streptozotocin treatment was not paralleled by an increase in the total number of spleen cells. Consequently, some Tcell populations appeared to be directly influenced by streptozotocin, which is a derivative of the wellrecognized carcinogen, 1-methyl-1-nitrosourea [15], which has potential cytotoxic actions that may be exerted through the liberation of alkylating moieties $[16,17]$. A loss of thymus tissue in streptozotocintreated mice has also been observed by Brown et al. $[8]$. Some investigators $[8,9]$ reported an alteration in the cellular immune responses of these diabetic animals but failed to report the time after streptozotocin that their mice were used. Consequently, it may be difficult to evaluate lymphocyte function using streptozotocin-induced diabetes as a model unless careful controls are employed. The reported ability of insulin to reverse the depressed granuloma formation observed in streptozotocin-diabetic animals [9] may be very much dependent upon the time after administration of the diabetogenic agent.

The spleen cells of streptozotocin-diabetic mice have essentially normal responses to Con A, but depressed MLC and cytotoxicity responses. These observations suggest that a clearer understanding of the direct effects of streptozotocin on lymphocytes will require a study of isolated $\mathrm{T}$-cell subpopulations. Cantor and Boyse $[18,19]$ have demonstrated that the effector $\mathrm{T}$ cells in lymphocyte-mediated cytotoxicity are distinct from a population of $T$ cells that may help or are required for the generation of killer cells. Other investigators [20] have reported that the cells proliferating in a MLC are not the cytotoxic effector cells. Therefore, the suppressed cytotoxicity and mixed-lymphocyte responses observed for spleen cells from streptozotocin animals may be explained by effects on one or more of the subpopulations of thymus-derived lymphocytes. In addition, both the MLC response and the generation of cytotoxic effector cells require the presence of macrophages [21-23]. Direct drug effects of the diabetic state in vivo may have influenced the distribution of $T$ cells as well as macrophages comprising the spleen cells studied in vitro.

Some evidence that insulin may directly influence glucose uptake and plasma membrane ATPase activity in lymphocytes has been reported by Hadden et al. [24]. Strom and coworkers [25] reported that physiological concentrations of insulin in vitro enhance the killing produced by cytotoxic effector cells generated in vivo. In addition, insulin receptors were present upon alloimmune $\mathrm{T}$ cells, but not upon nonimmune $T$-enriched cells or on $T$ cells from animals that received syngeneic grafts [26]. Therefore, some druginduced insulin-deficient diabetic models may be useful in identifying the population of $\mathrm{T}$ cells dependent upon insulin, but precautions must be taken to assess the direct immunosuppressive effects of diabetogenic agents such as streptozotocin. 
Acknowledgements. This work was supported by USPHS grants AM 16330 and HL 20125.

\section{References}

1. Johnson, J. E., III: Infection and diabetes. In: M. Ellenberg, $H$. Rifkin (Eds.): Diabetes Mellitus: Theory and Practice, pp. 734-745. New York: McGraw-Hill Book Company 1970

2. Editorial: Diabetes mellitus and pyelonephritis. N. Engl. J. Med. 261, 1247 (1959)

3. Ragab, A.H., Hazlett, B., Cowan, H.D.: Response of peripheral blood lymphocytes from patients with diabetes mellitus to phytohemagglutinin and candida albicans antigen. Diabetes 21, 906-907 (1972)

4. Brody, J. I., Morlie, K.: Metabolic and biosynthetic features of lymphocytes from patients with diabetes mellitus: similarities to lymphocytes in chronic lymphatic leukaemia. Br. J. Haematol. 19, 193-201 (1970)

5. MacCuish, A.C., Urbaniak, S.J., Campbell, C.J., Duncan, L. J.P., Irvine, W. J.: Phytohemagglutinin transformation and circulating lymphocyte subpopulations in insulin-dependent diabetics. Diabetes 23, 708-712 (1974)

6. Nichols, W.K.: The responsiveness of peripheral blood lymphocytes obtained from alloxan-diabetic rats to phytohemagglutinin. Fed. Proc. 32, 571 (1974)

7. Pallavicini, M.G., Nichols, W.K.: Inhibition of lymphocyte blastogenesis by factor(s) in alloxan-diabetic rat plasma. Diabetes 24, 614-622 (1976)

8. Brown, D. M., Yunis, E. J., Fernandes, G.: T-cell function in diabetic mice. Fed. Proc. 36, 1258 (1977)

9. Mahmoud, A. A. F., Rodman, H.M., Mandel, M. A., Warren, K. S.: Induced and spontaneous diabetes mellitus and suppression of cell-mediated immunologic responses. J. Clin. Invest. 57, 362-367 (1976)

10. Janossy, G., Greaves, M.F.: Lymphocyte activation. I. Response of $\mathrm{T}$ and $\mathrm{B}$ lymphocytes to phytomitogens. Clin. Exp. Immunol. 9, 483-498 (1971)

11. Shearer, G.M.: Cell-mediated cytotoxicity to trinitrophenyl syngeneic lymphocytes. Eur. J. Immunol. 4, 527-533 (1974)

12. Takasugi, M., Klein, E.: A microassay for cell-mediated immunity. Transplantation 9, 219-227 (1970)

13. Le Marchand, Y., Loten, E. G., Assimacopoulos-Jeannet, F., Forgue, M., Freychet, P., Jeanrenaud, B.: Effect of fasting and streptozotocin in the obese-hyperglycemic (ob/ob) mouse. Diabetes 26, 582-590 (1977)

14. Batchelor, B. R., Stern, J.S., Johnson, P.R., Mahler, R. J.: Effects of streptozotocin on glucose metabolism, insulin response, and adiposity in ob/ob mice. Metabolism 24, 77-91 (1975)
15. Herr, R. R., Jahnke, H. K., Argoudelis, A. D.: The structure of streptozotocin. J. Am. Chem. Soc. 69, 4808-4809 (1967)

16. Druckrey, H., Ivankovic, S., Preussman, R.: Selective Berzeugung maligner Tumoren in Gehirn und Rückenmark von Ratten durch N-Methyl-N-nitrosoharnstoff. Z. Krebsforsch. 66, 389-408 (1965)

17. Garrett, E. R., Prediction of stability in pharmaceutical preparations. VII. The solution degradation of the antibiotic streptozotocin. J. Am. Pharm. Assoc. 49, 767-777 (1960)

18. Cantor, H., Boyse, E. A.: Functional subclasses of T lymphocytes bearing differently antigens. $I$. The generation of functionally distinct $T$-cell subclasses is a differentiative process independent of antigen. J. Exp. Med. 141, 1376-1389 (1975)

19. Cantor, H., Boyse, E. A.: II. Cooperation between subclasses of $\mathrm{Ly}^{+}$cells in the generation of killer activity. J. Exp. Med. 141, 1390-1399 (1975)

20. Bach, F.H., Segall, M., Zeir, K.S., Sondel, P.M., Alter, B. J., Bach, M.L.: Cell-mediated immunity: Separation of cells involved in recognitive and destructive phases. Science 180, 403-406 (1973)

21. Alter, B. J., Bach, F. H.: Lymphocyte reactivity in vitro. I. Cellular reconstitution of purified lymphocyte response. Cell. Immunol. 1, 207-218 (1970)

22. Oppenheim, J. J., Levinthol, B. G., Hersh, E. M.: The transformation of column-purified lymphocyte response. Cell. Immunol. 1, 207-218 (1970)

23. Beaven, M. J., Epstein, R., Cohn, M.: The effect of $\alpha$-mercaptoethanol on murine mixed-lymphocyte cultures. J. Exp. Med. 139, 1025-1030 (1974)

24. Hadden, J.W., Hadden, E.M., Wilson, E. E., Good, R. A., Coffey, R.G.: Direct action of insulin on plasma membrane ATPase activity in human lymphocytes. Nature 235, 174-176 (1972)

25. Strom, T. B., Bear, R.A., Carpenter, C. B.: Insulin-induced augmentation of lymphocyte mediated cytotoxicity. Science 187, 1206-1208 (1975)

26. Helderman, J.H., Strom, T.B.: Emergence of insulin receptors upon alloimmune $\mathrm{T}$ cells in the rat. J. Clin. Invest. 59, 338-344 (1977)

Received: August 17, 1977

and in revised form: January 5, 1978

William K. Nichols

Department of Biopharmaceutical Sciences

College of Pharmacy

University of Utah

Salt Lake City, UT 84112

USA 